\title{
Effects of Estrogen Therapy on the Serotonergic System in an Animal Model of Perimenopause Induced by 4-Vinylcyclohexen Diepoxide (VCD)
}

\author{
Nayara Pestana-Oliveira, ${ }^{1}$ B Bruna Kalil, ${ }^{2}$ Cristiane Mota Leite, ${ }^{2}$ Ruither Oliveira Gomes Carolino, ${ }^{2}$ \\ Lucas Kniess Debarba, ${ }^{1}$ Lucila Leico Kagohara Elias, ${ }^{1}$ José Antunes-Rodrigues, ${ }^{1}$ and \\ Janete A. Anselmo-Franci ${ }^{2}$
}

DOI:http://dx.doi.org/10.1523/ENEURO.0247-17.2017

${ }^{1}$ Department of Physiology, School of Medicine of Ribeirão Preto, University of São Paulo, Ribeirão Preto, São Paulo, Brazil and ${ }^{2}$ Department of Morphology, Physiology and Basic Pathology, School of Dentistry of Ribeirão Preto, University of São Paulo, Ribeirão Preto, São Paulo, Brazil

\begin{abstract}
Chronic exposure to 4-vinylcycloxene diepoxide (VCD) in rodents accelerates the natural process of ovarian follicular atresia modelling perimenopause in women. We investigated why estrogen therapy is beneficial for symptomatic women despite normal or high estrogen levels during perimenopause. Female rats (28 d) were injected daily with VCD or oil for $15 \mathrm{~d}$; $55-65 \mathrm{~d}$ after the first injection, pellets of $17 \beta$-estradiol or oil were inserted subcutaneously. Around $20 \mathrm{~d}$ after, the rats were euthanized (control rats on diestrus and estradioltreated $21 \mathrm{~d}$ after pellets implants). Blood was collected for hormone measurement, the brains were removed and dorsal raphe nucleus (DRN), hippocampus (HPC), and amygdala (AMY) punched out for serotonin (5-HT), estrogen receptor $\beta(E R \beta)$, and progesterone receptor (PR) mRNA level measurements. Another set of rats was perfused for tryptophan hydroxylase (TPH) immunohistochemistry in the DRN. Periestropausal rats exhibited estradiol levels similar to controls and a lower progesterone level, which was restored by estradiol. The DRN of periestropausal rats exhibited lower expression of PR and ER $\beta$ mRNA and a lower number of TPH cells. Estradiol restored the ER $\beta$ mRNA levels and number of serotonergic cells in the DRN caudal subregion. The 5-HT levels were lower in the AMY and HPC in peristropausal rats, and estradiol treatment increased the 5-HT levels in the HPC and also increased ER $\beta$ expression in this area. In conclusion, estradiol may improve perimenopause symptoms by increasing progesterone and boosting serotonin pathway from the caudal DRN to the dorsal HPC potentially through an increment in ER $\beta$ expression in the DRN.
\end{abstract}

Key words: estrogen; estrogen receptor $\beta$; progesterone receptor; dorsal raphe nucleus; amygdala; hippocampus

\section{Significance Statement}

During the most part of menopausal transition, estradiol fluctuates in a normal range; however, estradiol therapy is effective in attenuating many of perimenopausal symptoms. We demonstrate in a perimenopause animal model that the expression of estrogen receptor $\beta(E R \beta)$ in serotonergic and hippocampal (HPC) neurons, both related to mood disorders, is reduced. Estradiol therapy reverses this deficiency, thus recovering the response of these areas to estrogens. There is also a decline in the number of brain serotonergic neurons and the amount of serotonin in the HPC, which are also reversed by estradiol. Therefore, estrogens therapies that target only $\beta$ receptors may be an alternative to obtain the beneficial effects of estradiol while eliminating the undesirable side effects of estrogens through $\alpha$ receptors. 


\section{Introduction}

At middle age, women progress from the reproductive (premenopause) to non-reproductive (postmenopause) life through a transition period named perimenopause (Harlow et al., 2012). During perimenopause, women may exhibit numerous symptoms, which include variability in cycle length, vasomotor symptoms, dysphoric mood symptoms, insomnia, and somatic symptoms (Mitchell and Woods, 1996; Diaz Brinton, 2012; Brinton et al., 2015). Regarding mood disorders, both epidemiological and clinical studies have consistently demonstrated that after puberty, the risk for depression is higher in women than men, and it reaches the maximum during perimenopause (Deecher et al., 2008).

Ovarian steroids, mainly estradiol and progesterone, affect brain regions involved in the modulation of mood and behavior (McEwen, 1989), and fluctuations in ovarian hormone secretion modify brain neurochemistry (Schmidt et al., 1998; Barth et al., 2015). Moreover, the emotional vulnerability windows that occur throughout women's lives are correlated with reproductive periods marked by considerable hormonal fluctuations, such as menstruation, pregnancy, postpartum period and perimenopause, thus indicating the pivotal role of sex steroids in the control of affective disorders (Stahl, 2001). The effects of estradiol and progesterone are predominately mediated by their nuclear cognate receptors: estrogen receptors (ERs) and progesterone receptors (PRs; Krege et al., 1998). These receptors are widely expressed in brain regions that control reproduction, as well as regions not typically linked with this function (Shughrue et al., 1997; Brinton et al., 2008; Weiser et al., 2008).

The hormonal profile of perimenopausal women is different from that observed in postmenopause. In postmenopausal women, levels of estrogens are extremely low, whereas in perimenopausal women, during the early and mid-perimenopause levels of estrogens are normal or even elevated compared to the premenopausal period (Reyes et al., 1977; Santoro and Randolph, 2011), and only at late perimenopause period, there is a significant

Received July 14, 2017; accepted December 16, 2017; First published January 4, 2018.

The authors declare no competing financial interests.

Author contributions: N.P.-O. and J.A.A.-F. designed research; N.P.-O., C.M.L., R.O.G.C., and L.K.D. performed research; L.L.K.E. and J.A.-R. contributed unpublished reagents/analytic tools; N.P.-O., B.K., and J.A.A.-F. analyzed data; N.P.-O., B.K., R.O.G.C., and J.A.A.-F. wrote the paper.

Acknowledgements: This work was supported by the Fundação de Amparo à Pesquisa do Estado de São Paulo Grant 2014/09772-9 and by the Conselho Nacional de Desenvolvimento Científico e Tecnológico Grant 300148/2010-0 and Coordenação de Aperfeiçoamento de Pessoal de Ensino Superior (CAPES/PROEX).

Correspondence should be addressed to Janete A. Anselmo-Franci, Departamento de Morfologia, Fisiologia e Patologia Básica, Faculdade de Odontologia de Ribeirão Preto, Universidade de São Paulo, Avenida do Café s/n, 14040-904, Ribeirão Preto, São Paulo, Brazil, E-mail: jaafranc@usp.br.

DOI:http://dx.doi.org/10.1523/ENEURO.0247-17.2017

Copyright (C) 2018 Pestana-Oliveira et al.

This is an open-access article distributed under the terms of the Creative Commons Attribution 4.0 International license, which permits unrestricted use, distribution and reproduction in any medium provided that the original work is properly attributed. decline on levels of estrogens (Burger et al., 1995; Santoro and Randolph, 2011).

Progesterone levels are clearly lower during perimenopause, which causes a misbalance in the estradiol/progesterone ratio (O'Connor et al., 2009). Considering the high estradiol and low progesterone level scenario, an intuitive treatment would be to supplement progesterone to counterbalance the estradiol dominance. However, there is no consensus about treatment of the symptomatic perimenopausal women and oral contraceptive or estrogen therapies are widely prescribed to relieve perimenopausal symptoms. Estradiol therapy improves several symptoms, such as vasomotor symptoms, thereby improving women's quality-of-life (Grant et al., 2015). Interestingly, while no correlation has been found between depression and estradiol levels during perimenopause, estrogen therapy is associated with significant improvements in the mood of perimenopausal women with depression symptoms (Schmidt et al., 2000; Soares et al., 2001). Therefore, considering the normal or high levels of estradiol during perimenopause, the use of extra doses of estrogen to ameliorate mood disorders in perimenopausal women is counterintuitive. Thus, to clarify this question, we raise three possibilities: (1) estradiol can increase the expression of PRs (MacLusky and McEwen, 1978; Helena et al., 2009), thus, it is reasonable to suggest that estrogen therapy, by increasing PR expression, compensates for the low plasma levels of progesterone; (2) as estrogen effects on mood predominately occur through ER $\beta$ (Bansal and Chopra, 2015; Bastos et al., 2015; Benmansour et al., 2016), estradiol therapy during perimenopause may positively modulate ER $\beta$ expression; and (3) because estrogens increases the activity of tryptophan hydroxylase (TPH), the rate-limiting enzyme in serotonin synthesis (Hiroi et al., 2006), it may rectify potential deviations in serotonin synthesis in the dorsal raphe nucleus (DRN), a central nucleus for the control of emotions. To test these hypotheses, we used an animal model of perimenopause in which the natural follicle depletion is accelerated by the 4-vinylcycloxene diepoxide (VCD) retaining residual ovarian tissue (Lohff et al., 2005). Unlike ovariectomized animals, in which the concentrations of ovarian hormones fall abruptly, this ovary-intact animal is suitable to model the natural women progression to perimenopause (Brooks et al., 2016). Thus, the aims of this study were evaluated whether follicular depletion induces alterations on: (1) the plasma concentrations of progesterone; (2) the ER $\beta$ and PR mRNA expression in the DRN, dorsal hippocampus (HPC) and amygdala (AMY); (3) the number of TPHimmunoreactive (ir) neurons in the DRN and d) the serotonin content in the dorsal HPC and AMY. Accordingly, we tested whether estradiol therapy can prevent the alterations observed in periestropausal rats.

\section{Materials and Methods}

\section{Animals}

Female Wistar rats at postnatal day (PND)21 were obtained from the animal facilities of the University of São Paulo; rats were housed four per plastic cage $(40 \times 33 \times$ $17 \mathrm{~cm}$ ) and maintained on 12/12 h light/dark cycles (lights 
on at 6:00 A.M.) at a controlled temperature $\left(24 \pm 0.5^{\circ} \mathrm{C}\right)$. Animals were allowed to acclimate to animal room condition for $7 \mathrm{~d}$ before the onset of VCD administration, which started at PND28, as described by Mayer et al. (2002). Food and water were provided ad libitum. All procedures were approved by the Committee for Animal Care and Use (2013.1.1412.58.7), University of São Paulo.

\section{VCD-induced perimenopausal model}

It has been shown that the oocyte number in rodents increases markedly toward the end of fetal life, but similar to women, many are lost as they assemble to form primordial follicles. Additionally, postnatal primordial follicles decline significantly for up to two weeks after birth followed by a period of very slow follicle loss, which lasts for several months (Kerr et al., 2013).

An ovary-intact rat model of perimenopause using the chemical, VCD (Mayer et al., 2004; Lohff et al., 2005), has been developed to accelerate the natural process of slow follicular loss. Repeated daily dosing with VCD for $15 \mathrm{~d}$ selectively destroys primordial and primary follicles in ovaries of mice and rats by accelerating atresia processes (Springer et al., 1996; Hu et al., 2001; Takai et al., 2003), thus inducing precocious perimenopause/menopause. The advantage of the VCD model over the surgically induced menopausal model (OVX), is that in VCD model ovarian steroids production do not ceases abruptly, as in OVX model, and the residual ovarian tissue produces androgens as in women. In addition, the time of OVX differs substantially among the studies generating conflicting results and misleading conclusions. Lastly, reproductive senescence in aging rodents seems to initiate centrally and not in the ovary as opposed to women (Gore et al., 2000; Kermath and Gore, 2012) therefore, aging rodents are not a good model as well.

The optimal VCD dose was determined as $160 \mathrm{mg} / \mathrm{kg}$ during $15 \mathrm{~d}$ (Mayer et al., 2004), and the subcutaneous administration route has been described as less harmful to the animals (Reis et al., 2014). This VCD dose was described as toxic only to ovarian follicles when administrated to juvenile rats (one-month-old), while in older rats (three-month-old), this same dose induced toxicity to other organs besides ovaries (Frye et al., 2012). Moreover, the administration of VCD at PND28 has the advantage to dissociate the effects of follicular depletion from those of aging by the time of the experiment when the rats are in periestropause but still young (around three to four months of age; Mayer et al., 2005; Van Kempen et al., 2011). It is important to note that this advantage is at the same time a limitation of the model. In one hand, the model allows to isolate the effects of follicular depletion from aging. In the other hand, the natural process of follicular depletion progress in parallel with aging, thus the resultant symptoms experienced during perimenopause can also result from of the impact of follicular depletion over aging and vice versa. Therefore, although ovaryintact model of perimenopause induced by VCD exposure in juvenile female rats is currently considered the model that more closely approximates to the natural human progression to menopause (Van Kempen et al., 2011), the interpretation of the results must be carefully addressed.

\section{Experimental design}

Peripubertal female rats at PND28 were injected daily with VCD (Sigma-Aldrich) subcutaneously administered at a dose of $160 \mathrm{mg} / \mathrm{kg}(128 \mathrm{mg} / \mathrm{ml}$ diluted in corn oil; 1.25 $\mathrm{ml} / \mathrm{kg}$ body weight) for $15 \mathrm{~d}$. Corn oil $(\mathrm{O} ; 1.25 \mathrm{ml} / \mathrm{kg}$ of body weight) was used in the control rats. Estrous cycle was monitored from day 65-85 after the onset of VCD treatment. Since the percentage of irregular cycle in our colony is around $20 \%$ in both $\mathrm{O}+\mathrm{O}$ and VCD + O groups, only rats cycling regularly were used in the experiment. Around 55-65 d after the first injection, pellets of $17 \beta$-estradiol $(E)$ or $O$ were implanted subcutaneously (groups $\mathrm{O}+\mathrm{O}$; VCD + O; VCD + E). Rats $\mathrm{O}+\mathrm{O}$ and VCD $+\mathrm{O}$ were decapitated between 75 and $85 \mathrm{~d}$ after the onset of VCD/Oil treatment between 9:00 and 11:00 A.M. of diestrus. VCD + E rats were decapitated exactly $21 \mathrm{~d}$ after the onset of $E$ therapy, regardless the phase of the estrous cycle, at the same time of the day. Following decapitation, trunk blood was collected for estradiol and progesterone measurements, the brain was removed, and the dorsal HPC and AMY were punched out to assess the 5-HT content by HPLC/ED and ER $\beta$ and PR mRNA levels. The DRN was dissected to analyze the $\operatorname{ER} \beta$ and PR mRNA levels. Another set of rats under the same experimental protocol was euthanized via perfusion for the immunohistochemical evaluation of TPH-positive cells in the DRN Fig. 1.

\section{Estrogen therapy}

Sillastic capsules filled with $8-\mu l \quad 17 \beta$-estradiol 50 $\mathrm{mg} / \mathrm{ml}$ (Sigma; group VCD $+\mathrm{E}$ ) or oil (groups $\mathrm{O}+\mathrm{O}$ and VCD + O) were subcutaneously implanted into the dorsolateral region of $\mathrm{VCD} / \mathrm{oil}$ female rats under anesthesia (55 $\mathrm{mg} / \mathrm{kg}$ ketamine, Agener; and $10 \mathrm{mg} / \mathrm{kg}$ xylazine, Coopers of Brazil; s.c.). Pellets were prepared as described previously (Kiss et al., 2012). After surgery, the animals received prophylactic antibiotic (Pentabiotico Fort Dodge; $0.2 \mathrm{ml} / \mathrm{rat}$, i.m.) and antiinflammatory treatment (Banamine, Schering-Plow; $2.5 \mathrm{mg} / \mathrm{kg}$, s.c.).

\section{Hormonal assays}

Trunk blood from decapitation was collected into heparinized tubes, and the plasma was stored frozen $\left(-20^{\circ} \mathrm{C}\right)$ for hormone assays. The plasma estradiol concentrations were determined via an ELISA estradiol kit (EIA 2693; DRG Instruments $\mathrm{GmbH}$ ). The progesterone concentrations were determined by radioimmunoassay (RIA) using specific kits provided by MP Biomedicals. The intraassay coefficients of variation were $4.7 \%$ and $3.6 \%$, and the lower limits of detection were $8.6 \mathrm{pg} / \mathrm{ml}$ and $0.02 \mathrm{ng} / \mathrm{ml}$ for estradiol and progesterone, respectively. All samples were measured in duplicate. To avoid interassay variation, all samples from the same experiment were measured in the same assay.

\section{Brain microdissections}

After decapitation, the brains were rapidly removed and frozen at $-70^{\circ} \mathrm{C}$. Microdissections were obtained accord- 

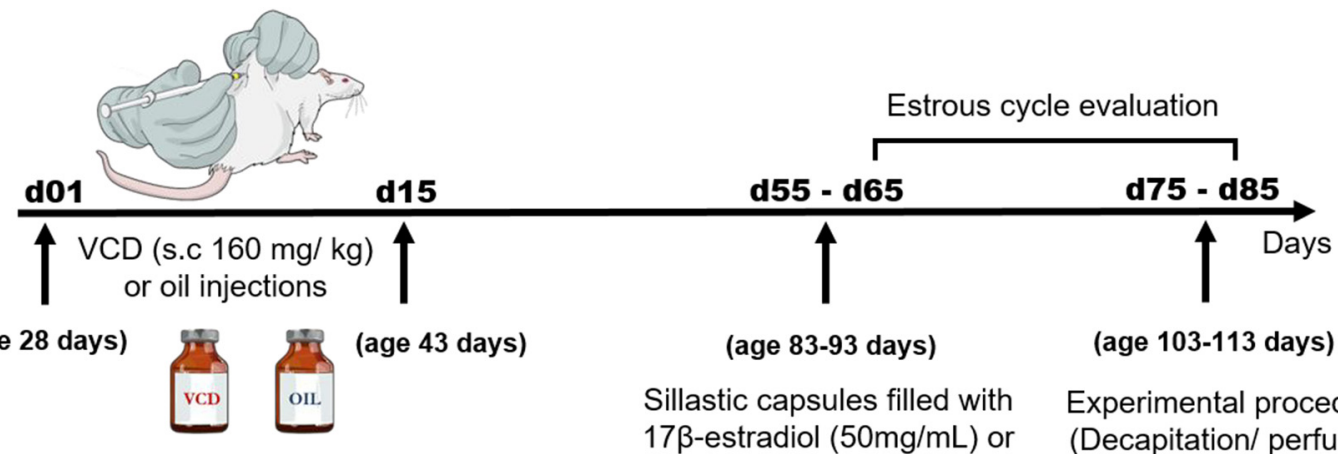

(age 83-93 days)

Sillastic capsules filled with $17 \beta$-estradiol $(50 \mathrm{mg} / \mathrm{mL})$ or corn oil (age 103-113 days)

Experimental procedures

(Decapitation/ perfusion)

Accelerated Follicular depletion

Figure 1. Schematic diagram showing the timeline of the experimental protocol.

ing to Palkovits (1973). The HPC and AMY were microdissected to assess the serotonin content, and DRN was microdissected to analyze the ER $\beta$ and PR mRNA expression. Thick coronal brain sections were cut in a cryostat at $-15^{\circ} \mathrm{C}$. For the AMY and dorsal HPC, a $1500-\mu \mathrm{m}$ section was obtained starting at approximately $-1.92 \mathrm{~mm}$ from bregma (Paxinos and Watson, 2007) and mounted onto chilled glass slides for microdissection using the punch technique (Palkovits, 1973). The AMY and dorsal HPC were dissected with 1.5- and 1.0-mm diameter needles, respectively. The DRN was dissected from one section of $1000 \mu \mathrm{m}$, from -7.2 mm from bregma (Paxinos and Watson, 2007), in one punch of each side of the brain with a 0.7-mm diameter needle.

\section{Serotonin content measurements (HPLC/ED)}

The 5-HT content was determined by HPLC coupled to an electrochemical detector. Briefly, microdissections of the dorsal HPC and AMY were individually homogenized in $100 \mu \mathrm{l}$ of a solution that contained $0.15 \mathrm{M}$ perchloric acid, $0.1 \mathrm{mM}$ EDTA and $380 \mathrm{nM}$ isoproterenol (ISOP; internal standard). Each homogenate was centrifuged at $15,700 \times g$ (for $5 \mathrm{~min}$ at $4^{\circ} \mathrm{C}$ ); the supernatants were filtered through a $0.22 \mu \mathrm{M}$ membrane (Durapore, Millipore) and subsequently injected into an HPLC system with an autoinjector (SIL-10ADVP; Shimadzu). The separation was performed at $32^{\circ} \mathrm{C}$ in a reverse phase column $250 \times 4 \mathrm{~mm}$ (Kinetex EVO C18, $5 \mu \mathrm{m}$; Phenomenex), preceded by a $4 \times 4 \mathrm{~mm}$ precolumn (Kinetex EVO C18, 5 $\mu \mathrm{m}$; Phenomenex). The mobile phase was composed of $75 \mathrm{mM}$ sodium dihydrogen phosphate, $10 \mathrm{mM}$ sodium chloride, $25 \mu \mathrm{M}$ EDTA, $1.7 \mathrm{mM}$ sodium 1-octansulfonic acid (Sigma-Aldrich), and 4\% methanol (Merck Chemical Inc.). The $\mathrm{pH}$ was adjusted to 3.0 with phosphoric acid. The flow rate of the pump (LC-10ADVP; Shimadzu) was $0.8 \mathrm{ml} / \mathrm{min}$, and the detector potential was $0.65 \mathrm{~V}$ (Decade; Antec). Each sample produced a chromatogram, which was recorded and analyzed with the software Class-VP (Shimadzu). 5-HT and ISOP were identified by their peak retention time and quantified by an internal standard method based on their peak height. All samples of each brain area were processed in the same analysis to avoid interassay variation. In the dorsal HPC and AMY, the intraassay variation was $6.1 \%$ and $5.0 \%$, respectively. For each sample, the 5-HT level was normalized to the protein content and expressed as picograms per microgram of protein $(\mathrm{pg} / \mu \mathrm{g})$.

\section{Quantitative real-time PCR}

Total RNA was isolated from the AMY and dorsal HPC samples using TRIzol reagent (Invitrogen) according to the manufacturer's protocol. The RNA concentrations were determined using a Nanodrop 2000c UV-Vis Spectrophotometer (Thermo Scientific). Quantitative real-time PCR for ER $\beta$ and PR were performed using a Step One Plus real-time PCR system purchased from Applied Biosystems. The TaqMan Genes Expression Assay used in this study was Rn00562610_m1 for ER $\beta$ (gene symbol: Ers2) and Rn01448227_m1 for PR (gene symbol: Pgr). Each PCR reaction was performed in triplicate. Water (instead of cDNA) was used as a negative control. The housekeeping genes for normalizing $\operatorname{ER} \beta$ and PR expression included $\beta$-actin (Rn00667869_m1). The determination of the gene transcript levels in each sample was obtained by the $\Delta \Delta C T$ method. For each sample, the threshold cycle (Ct) was determined and normalized to the average of the housekeeping gene $(\Delta \mathrm{Ct}=\mathrm{CtUnknown}$ - CtHousekeeping gene). The relative mRNA level in the unknown sample relative to the calibrator group $(\mathrm{O}+\mathrm{O}$ group) was calculated as $2^{-\Delta \Delta \mathrm{Ct}}$, where $\Delta \Delta \mathrm{Ct}=\Delta \mathrm{CtUnknown}-\Delta \mathrm{CtCalibrator}$ (Livak and Schmittgen, 2001).

\section{Perfusion and immunohistochemistry for TPH}

Rats were deeply anesthetized with ketamine (ketamine hydrochloride, Agner; $106 \mathrm{mg} / \mathrm{kg}$ ) and xylazine (xilasina, Coopazine, Coopers; $18.6 \mathrm{mg} / \mathrm{kg}$ ) and transcardially perfused with PBS, followed by ice-cold $4 \%$ paraformaldehyde. Serial coronal sections of $30 \mu \mathrm{m}$ were cut in four series that represented the antero-posterior length of the DRN. The immunolabeling of TPH was performed on free-floating sections $120 \mu \mathrm{m}$ apart. The sections were rinsed at room temperature in $0.01 \mathrm{M} \mathrm{PBS}(\mathrm{pH} \mathrm{7.3,3 \times 10}$ min), incubated for $10 \mathrm{~min}$ in $1 \%$ hydrogen peroxide, and rinsed again in $0.01 \mathrm{M}$ PBS $(5 \times 10 \mathrm{~min})$. The sections 
ESTRADIOL

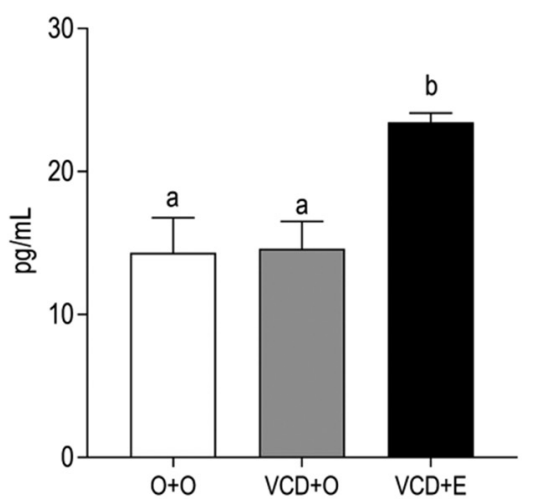

PROGESTERONE

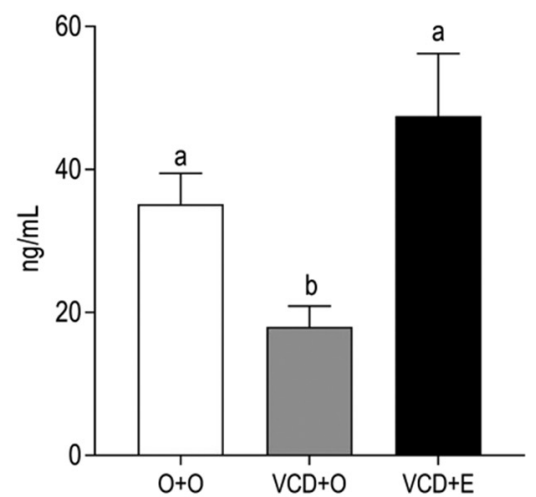

Figure 2. Effects of follicular depletion induced by VCD and chronic $17 \beta$-estradiol (E) treatment on estradiol (left panel) and progesterone (right panel) plasma concentrations. Female rats at $28 \mathrm{~d}$ of age were subcutaneously injected with corn oil (O) or VCD for 15 consecutive days. Fifty-five days after the first injection of VCD/oil, rats received a subcutaneous capsule that contained corn oil (groups $\mathrm{O}+\mathrm{O}$ and VCD $+\mathrm{O}$ ) or $17 \beta$-estradiol $(\mathrm{VCD}+\mathrm{E})$. Rats were decapitated during the diestrous phase $(\mathrm{O}+\mathrm{O}$ and VCD + O groups) or $21 \mathrm{~d}$ after the onset of $\mathrm{E}$ therapy (VCD + E), from 75 to $85 \mathrm{~d}$ after the onset of VCD/oil administration, between 9:00 and 11:00 A.M. Data are presented as the mean \pm SEM. Significance was defined as $p<0.05$. Different letters indicate significant differences $(n=6-9)$.

were subsequently incubated for $60 \mathrm{~min}$ at room temperature in PBS buffer that contained 1\% BSA (Sigma Chemical $\mathrm{Co}$ ) to block non-specific binding. The sections were incubated for $40 \mathrm{~h}$ at $4^{\circ} \mathrm{C}$ with sheep anti-TPH polyclonal antibody (1:2000; Millipore) and then washed in $0.01 \mathrm{M}$ PBS $(5 \times 5 \mathrm{~min})$ at room temperature. The sections were subsequently incubated with the biotinylated rabbit antisheep IgG (1:600; Vector Laboratories) for $1 \mathrm{~h}$ at room temperature. Signal amplification was performed using an avidin-biotin kit (1:100; Vector Laboratories) for $1 \mathrm{~h}$ at room temperature. A solution of $25 \mathrm{mg} / \mathrm{ml}$ nickel sulfate, $0.2 \mathrm{mg} / \mathrm{ml} \mathrm{3,3}$-diaminobenzidine- $\mathrm{HCl}$ (DAB) and $0.03 \%$ $\mathrm{H}_{2} \mathrm{O}_{2}$ (Ni-DAB) diluted in $0.175 \mathrm{M}$ sodium acetate was used as the chromogen. The sections were mounted on slides (Fisherbrand Superfrost Plus; Fisher Scientific) treated with subbing solution $(0.1 \%$ gelatin and $0.01 \%$ chromium potassium sulfate), allowed to dry in the dark, coverslipped with Entellan (Merck).

\section{Microscopy}

Brightfield imaging of TPH-ir neurons was performed using a Zeiss Axioskope 2 plus microscope. The number of TPH-ir neurons was quantified throughout the rostrocaudal extent of the DRN from bregma -7.32 to -8.58 $\mathrm{mm}$. The number of TPH-positive cells was analyzed at three anatomic levels, rostral $(-7.32 \mathrm{~mm}$ from bregma), mid $(-7.80 \mathrm{~mm}$ from bregma) and caudal $(-8.5 \mathrm{~mm}$ from bregma), each of which was divided into three subregions, including lateral, dorsal, and ventral regions, as previously described (Kunimura et al., 2015). Two sections from each level per animal were analyzed. The subsectional analyses of the DRN were performed on the basis of neuroanatomical data showing differential projection from distinct subregions of the DRN to a number of brain areas (Lowry, 2002; Michelsen et al., 2007). Digital images were subsequently converted to a tagged image file format and imported into Adobe Photoshop (Adobe Photoshop Lightroom, version 5.3; Adobe Systems, Inc.), in which the color balance was generally adjusted for presentation.

\section{Statistical analysis}

Except for gene expression, all comparisons were performed using one-way ANOVA followed by NewmanKeuls post hoc test. For gene expression, the comparison was performed in relation to the control group $(\mathrm{O}+\mathrm{O}$ group) using one-way ANOVA followed by Fisher's LSD test. Data are presented as the mean \pm SEM. Significance was accepted at $p \leq 0.05$. All statistical analyses and graphs were performed using GraphPad Prism software (GraphPad Software).

\section{Results}

The estradiol levels in the VCD $+O$ group did not vary compared with the $\mathrm{O}+\mathrm{O}$ group. As expected, after $21 \mathrm{~d}$ of $17 \beta$-estradiol therapy, the estradiol plasma concentrations were significantly higher in the VCD $+E$ animals than the other groups (Fig. 2, left panel; $p<0.001$ ). In the $\mathrm{VCD}+\mathrm{O}$ rats, plasma progesterone concentrations were significantly lower than in the $\mathrm{O}+\mathrm{O}$ group $(p<0.001)$, and estradiol treatment restored it to the control levels (Fig. 2, right panel).

In the DRN, the PR mRNA expression in the VCD + O was lower than the control rats $(p=0.0156)$, and this effect was not reversed by estradiol treatment (Fig. 3, left panel). Similarly, the rats in periestropause also expressed less mRNA for $\operatorname{ER} \beta$ ( $p=0.0409$ ); however, estradiol treatment was effective in reversing this effect (Fig. 3, right panel). As expected, immunoreactive TPH cells were identified throughout the rostral-caudal length of the DRN from bregma -7.32 to $-8.5 \mathrm{~mm}$ (Fig. $4 A-C$ ). The overall effect on TPH-positive cells in the entire DRN showed a decreased number of TPH-positive cells/section in VCDtreated animals compared to the control $(p=0.0062)$ that was partially restored by estradiol therapy $(\mathrm{O}+\mathrm{O} 119.3 \pm$ 12.48; VCD + O $67.73 \pm 9.107$; VCD + E $90.63 \pm 11.23$; 


\section{DRN}
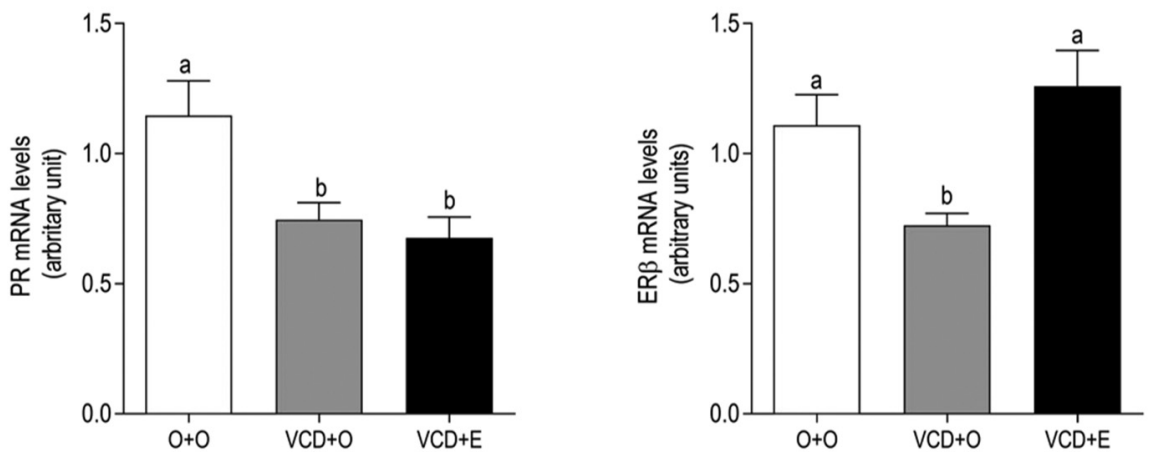

Figure 3. Effects of follicular depletion induced by VCD and chronic $17 \beta$-estradiol (E) administration on the relative mRNA expression of PR (left panel) and ER $\beta$ (right panel) in the DRN. Female rats at $28 \mathrm{~d}$ of age were subcutaneously injected with corn oil (O) or VCD for 15 consecutive days. Fifty-five days after the first injection of VCD/oil, rats received a subcutaneous capsule that contained corn oil (groups $\mathrm{O}+\mathrm{O}$ and VCD $+\mathrm{O}$ ) or $17 \beta$-estradiol $(\mathrm{VCD}+\mathrm{E})$. Rats were decapitated during the diestrous phase $(\mathrm{O}+\mathrm{O}$ and VCD + O groups) or $21 \mathrm{~d}$ after the onset of E therapy (VCD + E), from 75 to $85 \mathrm{~d}$ after the onset of VCD/oil administration, between 9:00 and 11:00 A.M. $(n=6-9)$. Data are presented as the mean \pm SEM. Significance was accepted at $p<0.05$.

Table 1). The number of TPH-positive cells was also analyzed separately at three anatomic levels, rostral, mid, and caudal, each of which was divided into three subregions, including the lateral, dorsal, and ventral regions (Fig. $4 A-C$ ). At the rostral part (Fig. 4, top bargraph panel), the number of TPH-positive cells in the VCD $+\mathrm{O}$ group was lower than in the $\mathrm{O}+\mathrm{O}$ group in the lateral and ventral parts of the DRN $(p<0.05)$. Estradiol therapy $(V C D+E)$ was able to restore the number of TPH-positive cells only in the ventral subregion $(p<0.001)$. On the other hand, estradiol effect on rostral-ventral subregion was not sufficient to reestablish the total amount of TPHpositive cells identified in the $\mathrm{O}+\mathrm{O}$ group. At the midlevel (Fig. 4, mid bargraph panel), the number of TPHpositive cells in the VCD + O group was lower than in the $\mathrm{O}+\mathrm{O}$ group in all subregions $(p<0.05)$ and estradiol therapy was able to restore the number of TPH-positive cells only in the lateral subregion $(p<0.05)$. Overall, estradiol treatment appeared to be ineffective in restoring the number of TPH cells at the mid-level of the DRN as demonstrated by the comparison of the total number of TPH-positive cells in the VCD + E group versus the VCD $+O$ group. At the caudal level (Fig. 4, lower bargraph panel), the lateral subregion was not affected by VCD and estradiol therapy. On the other hand, the number of TPHpositive cells was substantially decreased in the VCD $+O$ group in the dorsal and ventral subregions $(p<0.05$ and $p<0.001$, respectively); estradiol therapy was effective in reverting this effect in both subregions when analyzed individually $(p<0.05$ for caudal dorsal and $p<0.001$ for caudal-ventral subregions), as well as in the entire caudal level of the DRN when all subregions were analyzed collectively (total; $p<0.001$ ).

In the AMY and dorsal HPC, the levels of PR mRNA remained unaltered in all groups (Fig. $5 A, D$, respectively). The levels of ER $\beta$ mRNA in the dorsal HPC was higher in the VCD + E group than the $\mathrm{O}+\mathrm{O}$ and $\mathrm{VCD}+\mathrm{O}$ groups (Fig. $5 E ; p=0.0012$ ), while in AMY, the levels of $E R \beta$ mRNA remained unaltered in all groups (Fig. 5B). Regard- ing $5-\mathrm{HT}$, the VCD $+\mathrm{O}$ rats exhibited decreased $5-\mathrm{HT}$ in both areas, dorsal HPC (Fig. 5F; $p<0.05$ ) and AMY (Fig. $5 C ; p<0.05)$. However, estradiol therapy was effective in restoring 5-HT levels only in the dorsal HPC (Fig. 5F; $p<$ 0.05 vs $\mathrm{O}+\mathrm{O}$ and VCD $+\mathrm{O}$ groups). The data are summarized in Table 1, and the statistical analyses shown in detail in Table 2.

\section{Discussion}

The current clinical practice to ameliorate perimenopausal symptoms relies on the use of estradiol therapy, although perimenopausal women are not estradiol deficient. The present study contributes to the understanding of this paradox by providing evidence that estradiol therapy appears to improve perimenopause symptoms, at least in part, by increasing the biosynthesis of progesterone and boosting the serotonin pathway from the caudal DRN to the dorsal HPC potentially through an increment in ER $\beta$ expression in the DRN. The ability to upregulate ER $\beta$ expression appears to be the estradiol key function to rectify the impairments in the serotonergic system induced by ovarian follicle depletion.

In the perimenopause animal model induced by VCD, we have recently shown that the ovarian hormones changes are similar to those exhibited by women in perimenopause, i.e., estradiol plasma concentrations remain unchanged, whereas progesterone plasma concentrations are low (Reis et al., 2014). These data were confirmed in the present study, which indicated no changes in the estradiol levels and low levels of progesterone in periestropausal rats. The increased levels of estradiol in the estradiol-treated rats confirm the efficiency of treatment. Thus, since estradiol levels remain normal, many of the symptoms experienced by women during perimenopause might be ascribed to the low levels of progesterone. However, if estradiol therapy is initiated before the establishment of menopause, symptoms, such as hot flashes and mood disorders, are reduced (Wiklund et al., 1993; Morgan et al., 2007), which indicates that important 

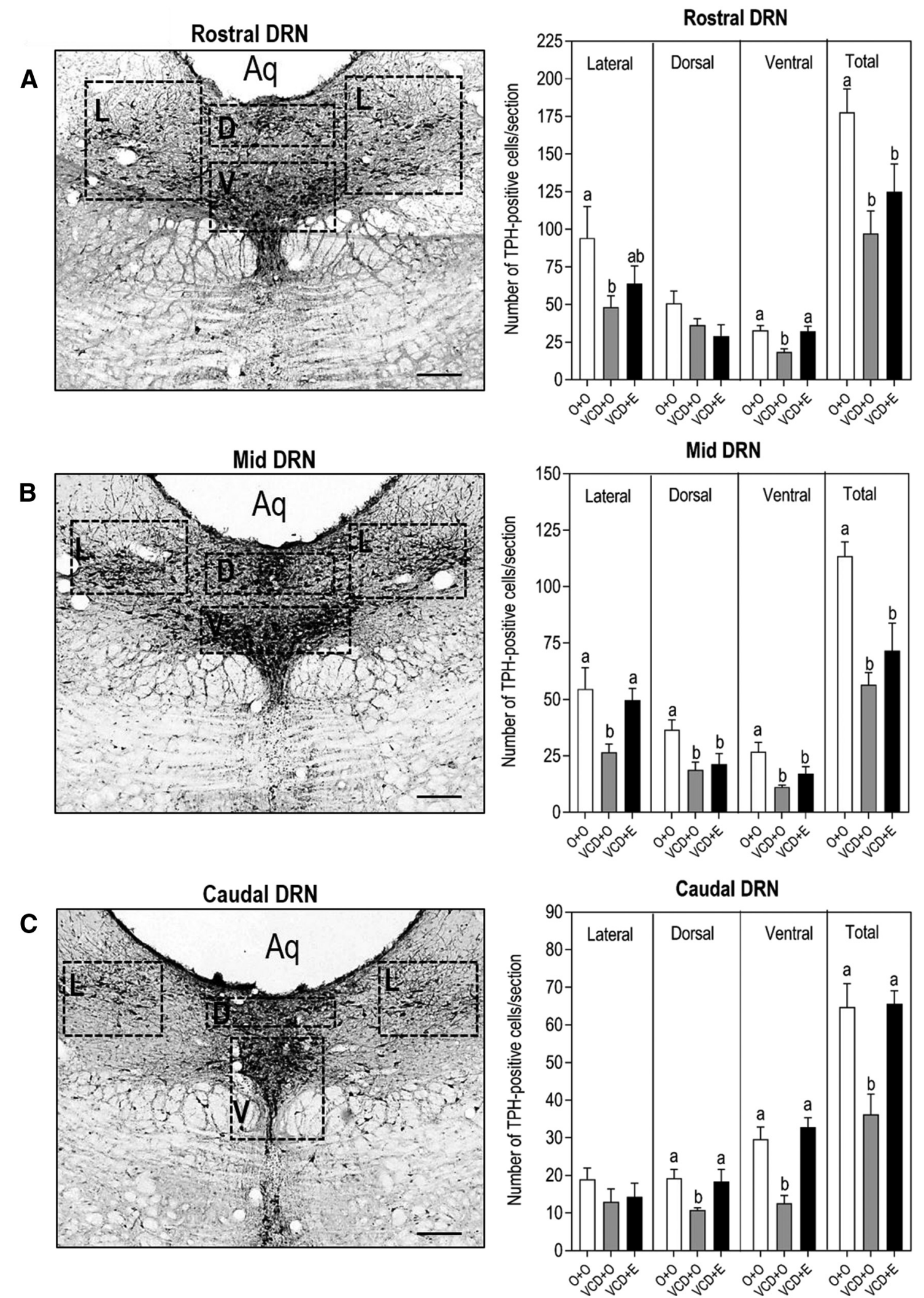

Figure 4. Effect of follicular depletion induced by VCD and chronic $17 \beta$-estradiol $(E)$ administration on TPH immunoreactivity in the DRN. Representative photomicrographies $(10 \times)$ of coronal sections of the DRN immunostained for TPH in rostral $(\boldsymbol{A} ;-7.32 \mathrm{~mm}$ from bregma), mid ( $\boldsymbol{B} ;-7.80 \mathrm{~mm}$ from bregma), and caudal $(\boldsymbol{C} ;-8.28 \mathrm{~mm}$ from bregma) sections of the DRN. Dotted boxes indicate the lateral (L), dorsal (D), and ventral (V) subregions at each level of the DRN. Aq, aqueduct. Scale bar: $50 \mu \mathrm{m}$. Bargraphs show the number of TPH-positive cells per section in the rostral (top panel), mid (mid panel), and caudal (lower panel) sections of the DRN. Female rats 
continued

at $28 \mathrm{~d}$ of age were subcutaneously injected with corn oil (O) or VCD for 15 consecutive days. Fifty-five days after the first injection of VCD/oil, rats received a subcutaneous capsule that contained corn oil (groups O $+\mathrm{O}$ and VCD $+\mathrm{O}$ ) or 17 $\beta$-estradiol (VCD + E). Rats were perfused during the diestrous phase $(\mathrm{O}+\mathrm{O}$ and VCD $+\mathrm{O}$ groups) or $21 \mathrm{~d}$ after the onset of $E$ therapy (VCD $+E)$, from 75 to $85 \mathrm{~d}$ after the onset of VCD/oil administration, between 9:00 and 11:00 A.M. These photomicrographies represent sections of a $\mathrm{O}+\mathrm{O}$ rat. Data are presented as the mean \pm SEM. Significance was accepted at $p<0.05$. Different letters indicate significant differences $(n=4-6)$.

changes in the brain biochemistry may occur as a result of ovarian senescence and estradiol signaling in the brain is somehow impaired. In this prism, the neurocircuitry responsive to estradiol becomes refractory, and exogenous estradiol would be necessary to reestablish the normal function.

Because progesterone levels were restored in response to estradiol therapy in periestropausal rats, it is reasonable to suppose that some of the estradiol beneficial effects appear to occur by adjusting progesterone levels. The mechanisms by which estradiol increases progesterone remain unclear; however, it has been shown that estradiol can modify steroidogenesis in the ovaries. In female rats, estradiol increases the activity of the enzyme 3 - $\beta$-hydroxysteroid dehydrogenase-isomerase (3- $\beta \mathrm{HSD}$ ) that catalyzes the conversion of pregnenolone to progesterone and reduces the activity of the enzyme 17-hydroxylase (17-OH), which cleaves progesterone to 17- $\mathrm{OH}$-progesterone (Munabi et al., 1983). Thus, by increasing synthesis and decreasing catabolism of progesterone, estradiol may induce an increase in the plasma progesterone concentrations. In addition, the production of progesterone in a hypothalamic astrocyte culture is also increased by estradiol (Micevych et al., 2008). Therefore, the peripheral and central progesterone may be increased in VCD rats treated with estradiol therapy.

Recent studies have established a relationship between perimenopausal symptoms and neuroprogestins, such as allopregnanolone (ALLO), a progesterone metabolite, which exerts anxiolytic effects by acting as an agonist on the $\mathrm{GABA}_{\mathrm{A}}$ (Lovick, 2006). Thus, it is possible that the beneficial effects of estradiol therapy during postmenopause occur through ALLO and progesterone. In accordance, low progesterone levels have been associated with mood swings that occur not only in perimenopause but also premenstrual syndrome and postpartum depres-

Table 1. Summary of estradiol therapy effects in the perimenopausal rat model

\begin{tabular}{lcc}
\hline Parameters & VCD + O VCD + E \\
Estradiol plasma concentration, pg/ml & $=$ & $\uparrow$ \\
Progesterone plasma concentration, ng/ml & $\downarrow$ & $=$ \\
PR mRNA levels in DRN, arbitrary units & $\downarrow$ & $\downarrow$ \\
ER $\beta$ mRNA levels in DRN, arbitrary units & $\downarrow$ & $=$ \\
Number of TPH-ir cells in total DRN & $\downarrow$ & $=$ \\
PR mRNA levels in AMY, arbitrary units & $=$ & $=$ \\
ER $\beta$ mRNA levels in AMY, arbitrary units & $=$ & $=$ \\
5-HT content in AMY, pg/ $\mu$ g protein & $\downarrow$ & $\downarrow$ \\
PR mRNA levels in HPC, arbitrary units & $=$ & $=$ \\
ER $\beta$ mRNA levels in HPC, arbitrary units & $=$ & $\uparrow$ \\
5-HT content in HPC, pg/ $\mu$ g protein & $\downarrow$ & $=$
\end{tabular}

All parameters were evaluated in the $\mathrm{VCD}+\mathrm{O}$ and $\mathrm{VCD}+\mathrm{E}$ groups in relation to the control $(\mathrm{O}+\mathrm{O})$. sion (Angst et al., 2001; Lovick, 2012; Lovick et al., 2017). Animal data have shown that progesterone reduces both anxiety and depressive behaviors in rodents (Mora et al., 1996; Walf et al., 2004; Frye, 2011), and as luteal progesterone drops during diestrus, rats exhibit anxiety-like behaviors, which are enhanced during periestropause (Reis et al., 2014). Altogether, these data suggest that low progesterone or increased estradiol to progesterone ratio might be involved in the development of some psychological symptoms in perimenopausal women.

As one of the major actions of estradiol is to induce PR expression in many regions of the CNS, including serotonergic neurons (MacLusky and McEwen, 1978; Bethea, 1994; Alves et al., 2000; Helena et al., 2009; Furuta et al., 2010) we hypothesized that estradiol could increase PR expression in the DRN because the effects of estradiol on the regulation of affective disorders appear to be, in part, through the serotonergic system. However, we have not found an increase on PR mRNA levels in any of the brain area evaluated in the present study. There are some important differences in our study in relation to previous works that might be generating conflicting results. Our results from periestropausal rats may be different from those of ovariectomized animals since their hormonal profile are different (Frye et al., 2012). Moreover, VCDtreated rats are still cycling, and it is known that PR regulation changes according to the phase of estrous cycle (Guerra-Araiza et al., 2000; Sá and Fonseca, 2017). In addition, PR regulation by estradiol changes with the reproductive status, region of the brain and age (Quadros and Wagner, 2008; Grieb et al., 2017). Finally, since it was shown that PR expression in response to estradiol is attenuated in old female rats compared to young rats (Furuta et al., 2010), we may hypothesize that the low PR expression in the periestropausal rats even with normal levels of estradiol represent a decrease on serotonergic neurons sensitivity to positive estradiol action, consistent with reproductive aging.

It has been postulated that $\mathrm{ER} \alpha$ signaling is closely related to reproductive function, whereas $\mathrm{ER} \beta$ signaling is relevant for non-reproductive functions, such as learning, memory and affective behavior (Rissman et al., 2002; Walf, 2010). In the DRN, ER $\beta$ is the predominant ER isoform, wherein $90 \%$ of the $\mathrm{ER} \beta$-ir neurons co-express TPH (Mitra et al., 2003; Nomura et al., 2005; Suzuki et al., 2013). Therefore, we investigated the expression of ER $\beta$ mRNA in the DRN of periestropausal rats. Our data showed that these rats exhibit lower expression of $E R \beta$ mRNA in the DRN compared with the control rats. Although there are no data regarding ER $\beta$ in perimenopause, it has been shown in mice and rats that there is a 

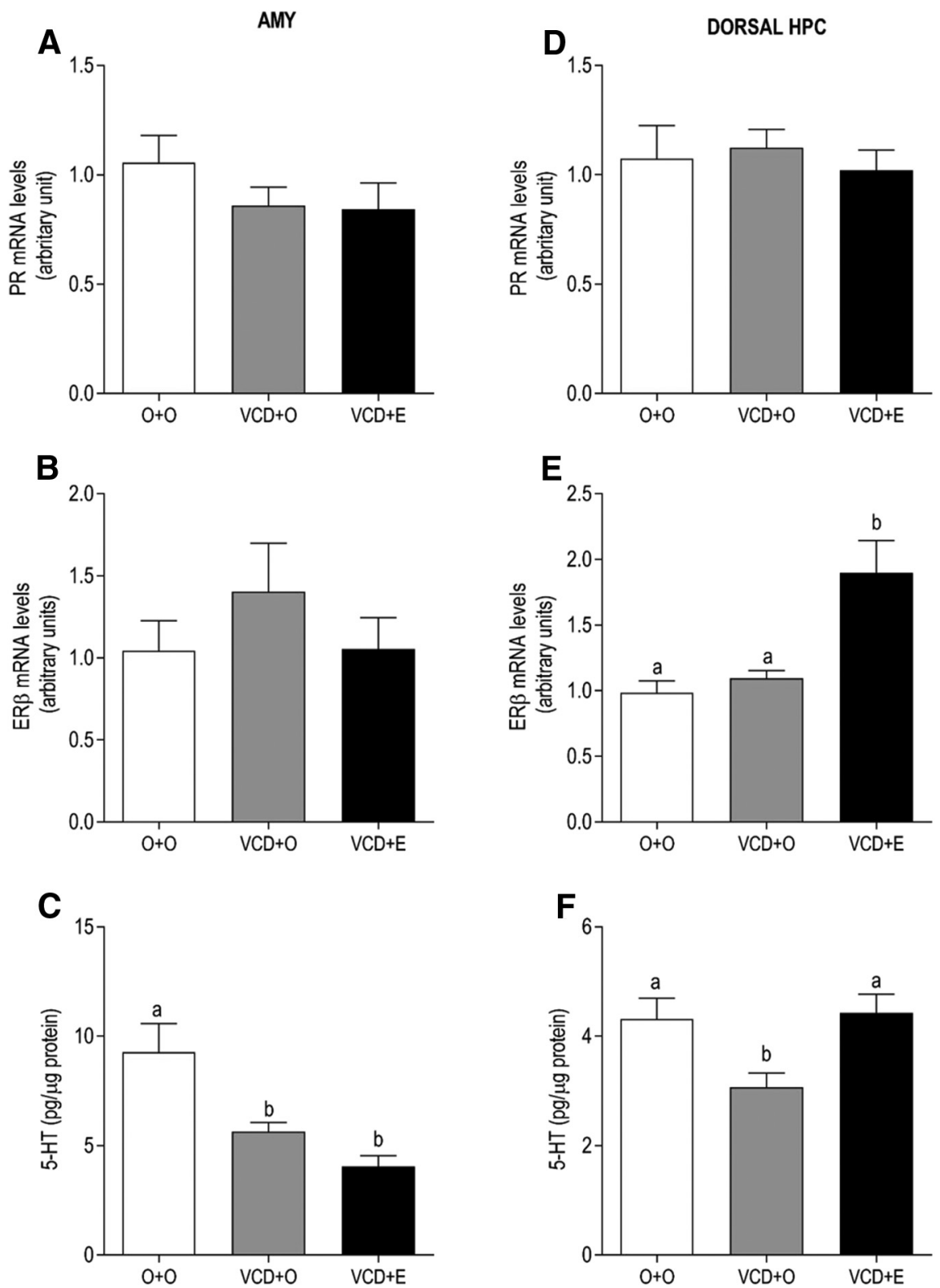

Figure 5. Effects of follicular depletion induced by VCD and chronic $17 \beta$-estradiol (E) administration on PR and ER $\beta$ mRNA levels and $5-\mathrm{HT}$ content in the AMY $(\boldsymbol{A}-\boldsymbol{C})$ and dorsal HPC $(\boldsymbol{D}-\boldsymbol{F})$. Female rats at $28 \mathrm{~d}$ of age were subcutaneously injected with corn oil (O) or VCD for 15 consecutive days. Fifty-five days after the first injection of VCD/oil, rats received a subcutaneous capsule that contained corn oil (groups $\mathrm{O}+\mathrm{O}$ and VCD $+\mathrm{O}$ ) or $17 \beta$-estradiol $(\mathrm{VCD}+\mathrm{E})$. Rats were decapitated during the diestrous phase $(\mathrm{O}+\mathrm{O}$ and VCD + O groups) or $21 \mathrm{~d}$ after the onset of E therapy (VCD + E), from 75 to $85 \mathrm{~d}$ after the onset of VCD/oil administration, between 9:00 and 11:00 A.M. Data are presented as the mean \pm SEM. Significance was accepted at $p<0.05$. Different letters indicate significant differences $(n=6-9)$.

generalized age-related decrease in the $\mathrm{ER} \beta$ levels in the cerebral cortex, HPC, olfactory bulb, AMY, and raphe nucleus, as well as other areas (Mehra et al., 2005; Sharma and Thakur, 2006; Yamaguchi-Shima and Yuri, 2007). However, in these studies, the comparison was made between young and middle-aged or old females, which makes it difficult to distinguish whether this decrease in $\mathrm{ER} \beta$ is a result of aging or ovarian senescence. In contrast, in the present study, all rats were around four months old; thus, the aging factor can be excluded. Moreover, it has been shown that ovariectomy induces a de- crease in $\mathrm{ER} \beta$-positive cells in the DRN, which is reversed by an $\operatorname{ER} \beta$ agonist (Suzuki et al., 2013). Our data indicated that the decrease of ER $\beta$ mRNA in the DRN of periestropausal rats was reversed by estradiol. This upregulation of $\mathrm{ER} \beta$ induced by estradiol appears to be exerted through $\mathrm{ER} \beta$ activation, because it has been shown that the selective $\mathrm{ER} \beta$ agonist LY3201 increases $\mathrm{ER} \beta$ expression in the DRN (Suzuki et al., 2013). It is well established that estradiol activation of $E R \beta$ signaling exerts antidepressant effects as a result of its excitatory actions on serotonergic neurons, which include increasing serotonin synthesis in 
Table 2. Statistical analyses performed in all experiments

\begin{tabular}{|c|c|c|c|c|}
\hline \multirow{2}{*}{$\begin{array}{l}\text { Figure } \\
2, \text { left panel }\end{array}$} & \multirow{2}{*}{$\begin{array}{l}\text { Data structure } \\
\text { Normal distribution }\end{array}$} & Type of test & \multicolumn{2}{|l|}{ Statistical results } \\
\hline & & $\begin{array}{l}\text { Ordinary one-way ANOVA } \\
\text { Newman-Keuls post hoc test } \\
\mathrm{O}+\mathrm{O} \text { vs VCD }+\mathrm{O} \\
\mathrm{O}+\mathrm{O} \text { vs VCD+E } \\
\text { VCD+O vs VCD+E }\end{array}$ & $F_{(2,18)}=10.06$ & $\begin{array}{l}/ p=0.0012 \\
p>0.05 \\
p<0.001 \\
p<0.001\end{array}$ \\
\hline 2 , right panel & Normal distribution & $\begin{array}{l}\text { Ordinary one-way ANOVA } \\
\text { Newman-Keuls post hoc test } \\
\mathrm{O}+\mathrm{O} \text { vs VCD }+\mathrm{O} \\
\mathrm{O}+\mathrm{O} \text { vs VCD+E } \\
\text { VCD+O vs VCD+E }\end{array}$ & $F_{(2,24)}=7.237$ & $\begin{array}{l}/ p=0.0035 \\
p<0.05 \\
p>0.05 \\
p<0.001\end{array}$ \\
\hline 3, left panel & Normal distribution & $\begin{array}{l}\text { Ordinary one-way ANOVA } \\
\text { Fisher's LSD } \\
\text { post hoc test }\end{array}$ & $\begin{array}{l}F_{(2,15)}=6.742 \\
95.00 \% \mathrm{Cl}\end{array}$ & $/ p=0.0082$ \\
\hline & & $\begin{array}{l}\mathrm{O}+\mathrm{O} \text { vs } \mathrm{VCD}+\mathrm{O} \\
\mathrm{O}+\mathrm{O} \text { vs } \mathrm{VCD}+\mathrm{E}\end{array}$ & $\begin{array}{l}0.0873 \text { to } 0.712 \\
0.1827 \text { to } 0.757\end{array}$ & $\begin{array}{l}/ p=0.0156 \\
/ p=0.0033\end{array}$ \\
\hline 3 , right panel & Normal distribution & $\begin{array}{l}\text { Ordinary one-way ANOVA } \\
\text { Fisher's LSD } \\
\text { post hoc test } \\
\text { O+O vs VCD }+\mathrm{O} \\
\mathrm{O}+\mathrm{O} \text { vs VCD }+\mathrm{E}\end{array}$ & $\begin{array}{l}F_{(2,16)}=4.921 \\
95.00 \% \mathrm{Cl} \\
0.0179 \text { to } 0.751 \\
-0.485 \text { to } 0.184\end{array}$ & $\begin{array}{l}/ p=0.0409 \\
/ p=0.3540\end{array}$ \\
\hline $4 A$ & Normal distribution & $\begin{array}{l}\text { Ordinary one-way ANOVA } \\
\text { Newman-Keuls post hoc test } \\
\text { Rostral-lateral DRN } \\
\mathrm{O}+\mathrm{O} \text { vs VCD }+\mathrm{O} \\
\mathrm{O}+\mathrm{O} \text { vs VCD+E } \\
\text { VCD+O vs VCD+E } \\
\text { Rostral-dorsal DRN } \\
\mathrm{O}+\mathrm{O} \text { vs VCD+O } \\
\mathrm{O}+\mathrm{O} \text { vs VCD+E } \\
\text { vCD+O vs VCD+E } \\
\text { Rostral-Ventral DRN } \\
\text { O+O vs VCD+O } \\
\mathrm{O}+\mathrm{O} \text { vs VCD+E } \\
\text { VCD+O vs VCD+E } \\
\text { Rostral-Total DRN } \\
\mathrm{O}+\mathrm{O} \text { vs VCD+O } \\
\mathrm{O}+\mathrm{O} \text { vs VCD+E } \\
\text { VCD+O vs VCD+E }\end{array}$ & $F_{(2,15)}=7.104$ & $\begin{array}{l}/ p=0.0337 \\
p<0.05 \\
p>0.05 \\
p>0.05 \\
/ p=0.2712 \\
p>0.05 \\
p>0.05 \\
p>0.05 \\
/ p=0.0068 \\
p<0.05 \\
p>0.05 \\
p<0.001 \\
/ p=0.0103 \\
p<0.001 \\
p<0.05 \\
p>0.05\end{array}$ \\
\hline $4 B$ & Normal distribution & $\begin{array}{l}\text { Ordinary one-way ANOVA } \\
\text { Newman-Keuls post hoc test } \\
\text { Mid-lateral DRN } \\
\mathrm{O}+\mathrm{O} \text { vs VCD }+\mathrm{O} \\
\mathrm{O}+\mathrm{O} \text { vs VCD+E } \\
\text { VCD+O vs VCD+E } \\
\text { Mid-dorsal DRN } \\
\mathrm{O}+\mathrm{O} \text { vs VCD+O } \\
\mathrm{O}+\mathrm{O} \text { vs VCD+E } \\
\text { VCD+O vs VCD+E } \\
\text { Midl-Ventral DRN } \\
\mathrm{O}+\mathrm{O} \text { vs VCD+O } \\
\mathrm{O}+\mathrm{O} \text { vs VCD+E } \\
\text { VCD+O vs VCD+E } \\
\text { Mid-Total DRN } \\
\mathrm{O}+\mathrm{O} \text { vs VCD+O } \\
\mathrm{O}+\mathrm{O} \text { vs VCD+E } \\
\text { VCD+O vs VCD+E } \\
\text { (Continued) }\end{array}$ & $\begin{array}{l}F_{(2,14)}=7.030 \\
F_{(2,14)}=13.30\end{array}$ & $\begin{array}{l}/ p=0.0240 \\
p<0.05 \\
p>0.05 \\
p<0.05 \\
/ p=0.0218 \\
p<0.05 \\
p<0.05 \\
p>0.05 \\
/ p=0.0077 \\
p<0.001 \\
p<0.05 \\
p>0.05 \\
/ p=0.0006 \\
p<0.0001 \\
p<0.001 \\
p>0.05\end{array}$ \\
\hline
\end{tabular}

the DRN (Lu et al., 1999; Bethea et al., 2000; Gundlah et al., 2005; Hiroi et al., 2006) and decreasing serotonin degradation by inhibiting monoamino-oxidase activity, thus increasing serotonin availability in the synaptic clefts (Luine and Rhodes, 1983; Ortega-Corona et al., 1994; Smith et al., 2004; Gundlah et al., 2005; Osterlund, 2010).
These actions and the increase in the firing rate of DRN neurons (Robichaud and Debonnel, 2005) induced by estradiol appear to be, at least in part, a result of the up regulation of $E R \beta$. Thus, in addition to the low progesterone levels, the decrease in estradiol signaling through $\mathrm{ER} \beta$ in the DRN may account for the development of 
Table 2. Continued

\begin{tabular}{|c|c|c|c|c|}
\hline \multirow{2}{*}{$\begin{array}{l}\text { Figure } \\
4 C\end{array}$} & \multirow{2}{*}{$\begin{array}{l}\text { Data structure } \\
\text { Normal distribution }\end{array}$} & Type of test & \multicolumn{2}{|l|}{ Statistical results } \\
\hline & & 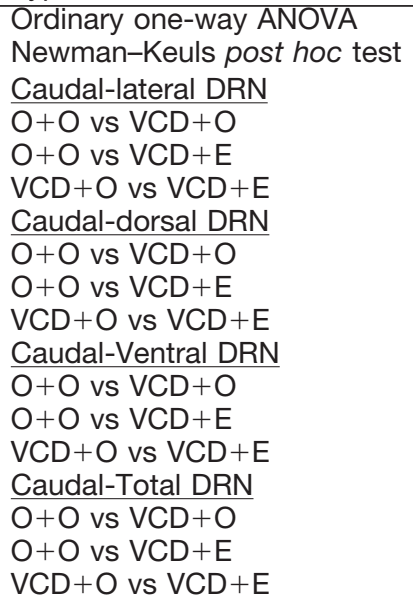 & $F_{(2,11)}=12.61$ & $\begin{array}{l}p=0.4009 \\
p>0.05 \\
p>0.05 \\
p>0.05 \\
/ p=0.05 \\
p<0.05 \\
p>0.05 \\
p<0.05 \\
/ p=0.0014 \\
p<0.001 \\
p>0.05 \\
p<0.001 \\
/ p=0.0052 \\
p<0.001 \\
p>0.05 \\
p<0.05\end{array}$ \\
\hline $5 A$ & Normal distribution & $\begin{array}{l}\text { Ordinary one-way ANOVA } \\
\text { Fisher's LSD post hoc test } \\
\text { O+O vs VCD }+O \\
\text { O+O vs VCD }+E\end{array}$ & $\begin{array}{l}F_{(2,23)}=1.172 \\
95.00 \% \mathrm{Cl} \\
-0.164 \text { to } 0.5585 \\
-0.1589 \text { to } 0.5858\end{array}$ & $\begin{array}{l}/ p=0.3276 \\
/ p=0.3476 \\
/ p=0.3157\end{array}$ \\
\hline $5 B$ & Normal distribution & $\begin{array}{l}\text { Ordinary one-way ANOVA } \\
\text { Fisher's LSD post hoc test } \\
\mathrm{O}+\mathrm{O} \text { vs VCD }+\mathrm{O} \\
\mathrm{O}+\mathrm{O} \text { vs VCD }+\mathrm{E}\end{array}$ & $\begin{array}{l}F_{(2,21)}=0.8078 \\
95.00 \% \mathrm{Cl} \\
-1.125 \text { to } 0.4039 \\
-0.7755 \text { to } 0.7531\end{array}$ & $\begin{array}{l}/ p=0.4592 \\
/ p=0.4415 \\
/ p=0.9991\end{array}$ \\
\hline $5 C$ & Normal distribution & $\begin{array}{l}\text { Ordinary one-way ANOVA } \\
\text { Newman-Keuls post hoc test } \\
\mathrm{O}+\mathrm{O} \text { vs VCD }+\mathrm{O} \\
\mathrm{O}+\mathrm{O} \text { vs VCD+E } \\
\text { VCD }+\mathrm{O} \text { vs VCD }+\mathrm{E}\end{array}$ & $F_{(2,20)}=9.697$ & $\begin{array}{l}/ p=0.0011 \\
p<0.001 \\
p<0.0001 \\
p>0.05\end{array}$ \\
\hline $5 D$ & Normal distribution & $\begin{array}{l}\text { Ordinary one-way ANOVA } \\
\text { Fisher's LSD post hoc test } \\
\text { O+O vs VCD+O } \\
\text { O+O vs VCD+E }\end{array}$ & $\begin{array}{l}F_{(2,21)}=0.2073 \\
95.00 \% \mathrm{Cl} \\
-0.4267 \text { to } 0.3285 \\
-0.3241 \text { to } 0.431\end{array}$ & $\begin{array}{l}/ p=0.8144 \\
/ p=0.9333 \\
/ p=0.9216\end{array}$ \\
\hline $5 E$ & Normal distribution & $\begin{array}{l}\text { Ordinary one-way ANOVA } \\
\text { Fisher's LSD post hoc test } \\
\mathrm{O}+\mathrm{O} \text { vs VCD }+\mathrm{O} \\
\mathrm{O}+\mathrm{O} \text { vs VCD }+\mathrm{E}\end{array}$ & $\begin{array}{l}F_{(2,16)}=10.95 \\
95.00 \% \mathrm{Cl} \\
-0.6103 \text { to } 0.3933 \\
-1.433 \text { to }-0.3916\end{array}$ & $\begin{array}{l}/ p=0.0010 \\
/ p=0.8228 \\
/ p=0.0012\end{array}$ \\
\hline $5 F$ & Normal distribution & $\begin{array}{l}\text { Ordinary one-way ANOVA } \\
\text { Newman-Keuls post hoc test } \\
\mathrm{O}+\mathrm{O} \text { vs VCD }+\mathrm{O} \\
\mathrm{O}+\mathrm{O} \text { vs VCD }+\mathrm{E} \\
\text { VCD }+\mathrm{O} \text { vs VCD }+\mathrm{E}\end{array}$ & $F_{(2,16)}=4.797$ & $\begin{array}{l}/ p=0.0233 \\
p<0.05 \\
p>0.05 \\
p<0.05\end{array}$ \\
\hline
\end{tabular}

some perimenopausal symptoms. The DRN is composed of distinct subregions that project to different sites of the brain to control in an independent, yet integrative manner different physiologic and behavioral processes (Graeff et al., 1996). In the present study, most subregions in the rostral, mid, and caudal DRN of periestropausal rats exhibited a reduced number of TPH-ir neurons associated with the decrease in the ER $\beta$ mRNA levels in this nucleus. Nevertheless, estradiol therapy was able to selectively increase the number of TPH-ir neurons only in a few subregions of the DRN related to the control of stress-related brain areas and emotional behaviors, such as the rostralventral DRN, the mid-lateral DRN and caudal dorsal-ventral DRN. It is not possible to correlate with certainty functional properties based only in the topographical distribution of serotonergic neurons within the nucleus. However, electrophysiological studies in behaving animals have provided important findings that indicate functional specialization of topographically organized subpopulations of serotonergic neurons (for review, see Lowry, 2002). The physiologic relevance of the increase of TPH-ir cells induced by estradiol in the mid-lateral DRN is unclear. However, it has been shown that the lateral wings of the mid DRN send projections to the arcuate and ventromedial nuclei of the hypothalamus and the lateral and ventral posterior nuclei of the thalamus and may be involved in the regulation of many physiologic processes (Monti, 2010).

The HPC and the AMY are the main limbic structures targeted by DRN efferent projections. The mid-dorsal DRN sends out collaterals to the basolateral and central AMY (Lowry, 2002), potentially to regulate anxiety-related behavior. The subregion analyses of the DRN revealed genuine topographical differences on serotonergic response to estradiol. It has been shown previously that distinct subregions of the DRN projects to different target areas in the brain (Michelsen et al., 2007). Together, the 
differential projections and responsiveness to estradiol may explain many of the paradoxical effects of estradiol in the brain. The sole analysis of estradiol effect in total DRN seems to cover estradiol selective modulation of DRN serotonergic neurons. The mechanism by which estradiol selectively upregulates the number of serotonergic neurons in DRN subregions is unknown. However, the existence of subpopulations of serotonergic neurons that differ in morphology, phenotype and receptor type warrants further investigation.

In periestropausal rats, TPH-ir neurons were reduced in the mid-dorsal DRN in association with a reduction in the serotonin content in the AMY. Estradiol therapy was unable to restore the number of TPH-ir neurons in the middorsal DRN or the serotonin content in the AMY. Because no changes were identified in the expression of PR and $\mathrm{ER} \beta$, the mid-dorsal DRN/AMY serotonergic circuit appears to be regulated by a factor other than directly by the ovarian steroids.

The serotonergic fibers that originate from the caudal DRN, close to the midline, innervate the HPC (Michelsen et al., 2007). In periestropausal rats, the decreased number of TPH-ir neurons in the dorsal and ventral subregions of the caudal DRN may explain the lower content of serotonin in the HPC. In accordance, estradiol treatment restored the number of TPH-ir neurons in the caudal DRN in association with the recovery of the serotonin content in the HPC. The HPC is more closely related to depression, whereas the AMY is related to anxiety (Graeff et al., 1996); suggesting a possible pathway by which estradiol therapy to perimenopausal women could be beneficial to treat depression. Accordingly, it has been shown that the administration of ER antagonists to the HPC, but not the AMY, increase anxiety and depression-like behaviors in rodents, which suggests that ERs in the HPC are a critical site for estradiol antianxiety and antidepressant-like effects (for review, see Walf and Frye, 2007). Furthermore, the antidepressant effects of estradiol on serotonergic neurotransmission and depressive behavior appear to be mediated preferentially via ER $\beta$. For example, selective agonists for $\mathrm{ER} \beta$, but not $\mathrm{ER} \alpha$, produced antidepressant effects, such as decreased immobility and increased struggling and swimming in the forced swim test in rats (Walf et al., 2004; Rocha et al., 2005; Clark et al., 2012; Bansal and Chopra, 2015; Bastos et al., 2015; Benmansour et al., 2016). In addition, the antidepressant activity of estradiol has been shown to be absent in knockout mice for ER $\beta$ (Rocha et al., 2005). Moreover, recent reports have demonstrated that female mice lacking $\operatorname{ER} \beta$ leads to dysregulation of brain-derived neurotrophic factor and serotonin signaling and decrease synaptic plasticity in the HPC, which could predispose the brain to a state of depression (Chhibber et al., 2017). Likewise, ER $\beta$ selective ligand reduces depressive-like behavior in ovariectomized mice (Sasayama et al., 2017).

In the present study, the PR and ER $\beta$ mRNA levels in the HPC of periestropausal rats are identical to the control rats; nevertheless, estradiol therapy increased the levels of ER $\beta$ but not PR mRNA. The upregulation of ER $\beta$ expression in the DRN and HPC appears to be the mecha- nism by which estradiol therapy improves psychological symptoms in perimenopausal women that are not estradiol deficient. For example, it has been shown that estradiol therapy increases the serotonin turnover rate in the HPC of adult female rats (Kiss et al., 2012), and the administration of DPN, a selective agonist for $E R \beta$, into this area decreases anxiety and depressive behaviors of ovariectomized rats (Walf and Frye, 2007). Interestingly, the intracellular effects of DPN in rat HPC neurons are similar to those obtained following treatment with sertraline, a widely used inhibitor of serotonin reuptake (Benmansour et al., 2016). Finally, it has also been shown that local application of DPN into the HPC induces slowing of 5-HT clearance, whereas an $\mathrm{ER} \alpha$ agonist blocks the fluvoxamine inhibitory effect on 5-HT clearance (Benmansour et al., 2012); these findings suggest that estradiol may operate as an antidepressive through the activation of $\mathrm{ER} \beta$ within the DRN to increase the serotonergic output to the HPC and/or directly via the activation of $\operatorname{ER} \beta$ within the HPC.

In conclusion, our data provide novel neuroendocrine insights into the understanding of the positive effect of estradiol therapy on perimenopausal symptoms in normoestrogenic perimenopausal women. We have shown that periestropausal rats display low progesterone plasma levels and a reduced number of serotonin neurons and ER $\beta$ mRNA levels in the DRN, as well as a reduced serotonin content in the AMY and HPC. The positive effects of estradiol therapy during perimenopause appear to result, at least in part, from the increase in peripheral progesterone biosynthesis in association with an upregulation of ER $\beta$ in the DRN and dorsal HPC that appears to potentiate the DRN/dorsal HPC serotonergic circuit. Therefore, the development of new therapies to target $\mathrm{ER} \beta$ may be an alternative to obtain the positive effects of estradiol action while eliminating the side effects of estradiol therapies that typically result from $\mathrm{ER} \alpha$ activation.

\section{References}

Alves SE, McEwen BS, Hayashi S, Korach KS, Pfaff DW, Ogawa S (2000) Estrogen-regulated progestin receptors are found in the midbrain raphe but not hippocampus of estrogen receptor alpha (ER alpha) gene-disrupted mice. J Comp Neur 427:185-195. CrossRef

Angst J, Sellaro R, Merikangas KR, Endicott J (2001) The epidemiology of perimenstrual psychological symptoms. Acta Psychiatr Scand 104:110-116. Medline

Bansal S, Chopra K (2015) Differential role of estrogen receptor modulators in depression-like behavior and memory impairment in rats with postmenopausal diabetes. Menopause 22:1117-1124. CrossRef Medline

Barth C, Villringer A, Sacher J (2015) Sex hormones affect neurotransmitters and shape the adult female brain during hormonal transition periods. Front Neurosci 9:37. CrossRef Medline

Bastos CP, Pereira LM, Ferreira-Vieira TH, Drumond LE, Massensini AR, Moraes MFD, Pereira GS (2015) Object recognition memory deficit and depressive-like behavior caused by chronic ovariectomy can be transitorialy recovered by the acute activation of hippocampal estrogen receptors. Psychoneuroendocrinology 57: 14-25. CrossRef

Benmansour S, Weaver RS, Barton AK, Adeniji OS, Frazer A (2012) Comparison of the effects of estradiol and progesterone on serotonergic function. Biol Psychiatry 71:633-641. CrossRef Medline 
Benmansour S, Adeniji OS, Privratsky AA, Frazer A (2016) Effects of long-term treatment with estradiol and estrogen receptor subtype agonists on serotonergic function in ovariectomized rats. Neuroendocrinology 103:269-281. CrossRef Medline

Bethea CL (1994) Regulation of progestin receptors in raphe neurons of steroid-treated monkeys. Neuroendocrinology 60:50-61. Medline

Bethea CL, Mirkes SJ, Shively CA, Adams MR (2000) Steroid regulation of tryptophan hydroxylase protein in the dorsal raphe of macaques. Biol Psychiatry 47:562-576. Medline

Brinton RD, Thompson RF, Foy MR, Baudry M, Wang J, Finch CE, Morgan TE, Pike CJ, Mack WJ, Stanczyk FZ, Nilsen J (2008) Progesterone receptors: form and function in brain. Front Neuroendocrinol 29:313-339. CrossRef Medline

Brinton RD, Yao J, Yin F, Mack WJ, Cadenas E (2015) Perimenopause as a neurological transition state. Nat Rev Endocrinol 11: 393-405. CrossRef Medline

Brooks HL, Pollow DP, Hoyer PB (2016) The VCD Mouse Model of Menopause and Perimenopause for the Study of Sex Differences in Cardiovascular Disease and the Metabolic Syndrome. Jul;31(4): 250-257. CrossRef

Burger HG, Dudley EC, Hopper JL, Shelley JM, Green A, Smith A, Dennerstein L, Morse C (1995) The endocrinology of the menopausal transition: a cross-sectional study of a population-based sample. J Clin Endocrinol Metab 80:3537-3545.

Chhibber A, Woody SK, Karim Rumi MA, Soares MJ, Zhao L (2017) Estrogen receptor $\beta$ deficiency impairs BDNF-5-HT 2A signaling in the hippocampus of female brain: a possible mechanism for menopausal depression. Psychoneuroendocrinology 82:107-116. CrossRef

Clark JA, Alves S, Gundlah C, Rocha B, Birzin ET, Cai SJ, Flick R, Hayes E, Ho K, Warrier S, Pai L, Yudkovitz J, Fleischer R, Colwell L, Li S, Wilkinson H, Schaeffer J, Wilkening R, Mattingly E, Hammond M, et al. (2012) Selective estrogen receptor-beta (SERM-beta) compounds modulate raphe nuclei tryptophan hydroxylase-1 (TPH-1) mRNA expression and cause antidepressant-like effects in the forced swim test. Neuropharmacology 63:1051-1063. CrossRef Medline

Deecher D, Andree TH, Sloan D, Schechter LE (2008) From menarche to menopause: exploring the underlying biology of depression in women experiencing hormonal changes. Psychoneuroendocrinology 33:317. CrossRef Medline

Diaz Brinton R (2012) Minireview: translational animal models of human menopause: challenges and emerging opportunities. Endocrinology 153:3571-3578. CrossRef Medline

Frye CA (2011) Progesterone reduces depressive behavior of young ovariectomized, aged progestin receptor knockout, and aged wild type mice in the tail suspension test. J Psychopharmacol 25:421428. CrossRef

Frye JB, Lukefahr AL, Wright LE, Marion SL, Hoyer PB, Funk JL (2012) Modeling perimenopause in Sprague-Dawley rats by chemical manipulation of the transition to ovarian failure. Comp Med 62:193-202. Medline

Furuta M, Fukushima A, Chiba S, Sano A, Akema T, Kimura F, Funabashi T (2010) Progesterone receptor immunoreactivity in the brains of ovariectomized aged rats. Neuroreport 21:777-781. CrossRef Medline

Gore AC, Oung T, Yung S, Flagg RA, Woller MJ (2000) Neuroendocrine mechanisms for reproductive senescence in the female rat: gonadotropin-releasing hormone neurons. Endocrine 13:315-323. CrossRef Medline

Graeff FG, Guimarães FS, De Andrade TG, Deakin JF (1996) Role of 5-HT in stress, anxiety, and depression. Pharmacol Biochem Behav 54:129-141. Medline

Grant MD, Marbella A, Wang AT, Pines E, Hoag J, Bonnell C, Ziegler KM, Aronson N (2015) Menopausal symptoms: comparative effectiveness of therapies. Rockville: Agency for Healthcare Research and Quality.

Grieb ZA, Tierney SM, Lonstein JS (2017) Postpartum inhibition of ovarian steroid action increases aspects of maternal caregiving and reduces medial preoptic area progesterone receptor expression in female rats. Horm Behav 96:31-41. CrossRef Medline

Guerra-Araiza C, Cerbón MA, Morimoto S, Camacho-Arroyo I (2000) Progesterone receptor isoforms expression pattern in the rat brain during the estrous cycle. Life Sci 66:1743-1752. Medline

Gundlah C, Alves SE, Clark JA, Pai L-Y, Schaeffer JM, Rohrer SP (2005) Estrogen receptor-beta regulates tryptophan hydroxylase-1 expression in the murine midbrain raphe. Biol Psychiatry 57:938942. CrossRef Medline

Harlow SD, Gass M, Hall JE, Lobo R, Maki P, Rebar RW, Sherman S, Sluss PM, de Villiers TJ; STRAW + 10 Collaborative Group (2012) Executive summary of the stages of reproductive aging workshop +10 : addressing the unfinished agenda of staging reproductive aging. J Clin Endocrinol Metab 97:1159-1168. CrossRef

Helena CV, Szawka RE, Anselmo-Franci JA (2009) Noradrenaline involvement in the negative-feedback effects of ovarian steroids on luteinising hormone secretion. J Neuroendocrinol 21:805-812. CrossRef Medline

Hiroi R, McDevitt RA, Neumaier JF (2006) Estrogen selectively increases tryptophan hydroxylase-2 mRNA expression in distinct subregions of rat midbrain raphe nucleus: association between gene expression and anxiety behavior in the open field. Biol Psychiatry 60:288-295. CrossRef Medline

Hu X, Christian PJ, Thompson KE, Sipes IG, Hoyer PB (2001) Apoptosis induced in rats by 4-vinylcyclohexene diepoxide is associated with activation of the caspase cascades. Biol Reprod 65:8793. Medline

Kermath BA, Gore AC (2012) Neuroendocrine control of the transition to reproductive senescence: lessons learned from the female rodent model. Neuroendocrinology 96:1-12. CrossRef Medline

Kerr JB, Myers M, Anderson RA (2013) The dynamics of the primordial follicle reserve. Reproduction 146:R205-R215. CrossRef Medline

Kiss A, Delattre AM, Pereira SIR, Carolino RG, Szawka RE, AnselmoFranci JA, Zanata SM, Ferraz AC (2012) $17 \beta$-estradiol replacement in young, adult and middle-aged female ovariectomized rats promotes improvement of spatial reference memory and an antidepressant effect and alters monoamines and BDNF levels in memory- and depression-related brain areas. Behav Brain Res 227:100-108. CrossRef

Krege JH, Hodgin JB, Couse JF, Enmark E, Warner M, Mahler JF, Sar M, Korach KS, Gustafsson JA, Smithies O (1998) Generation and reproductive phenotypes of mice lacking estrogen receptor beta. Proc Natl Acad Sci USA 95:15677-15682. Medline

Kunimura Y, Iwata K, lijima N, Kobayashi M, Ozawa H (2015) Effect of sex steroid hormones on the number of serotonergic neurons in rat dorsal raphe nucleus. Neurosci Lett 594:127-132. CrossRef Medline

Livak KJ, Schmittgen TD (2001) Analysis of relative gene expression data using real-time quantitative PCR and the 2(-Delta Delta $C(T)$ ) Method. Methods 25:402-408. CrossRef

Lohff JC, Christian PJ, Marion SL, Arrandale A, Hoyer PB (2005) Characterization of cyclicity and hormonal profile with impending ovarian failure in a novel chemical-induced mouse model of perimenopause. Comp Med 55:523-527.

Lovick TA (2006) Plasticity of GABA A receptor subunit expression during the oestrous cycle of the rat: implications for premenstrual syndrome in women. Exp Physiol 91:655-660. CrossRef Medline

Lovick TA (2012) Estrous cycle and stress: influence of progesterone on the female brain. Braz J Med Biol Res 45:314-320. CrossRef

Lovick TA, Guapo VG, Anselmo-Franci JA, Loureiro CM, Faleiros MCM, Del Ben CM, Brandão ML (2017) A specific profile of luteal phase progesterone is associated with the development of premenstrual symptoms. Psychoneuroendocrinology 75:83-90. CrossRef Medline

Lowry CA (2002) Functional subsets of serotonergic neurones: implications for control of the hypothalamic-pituitary-adrenal axis. J Neuroendocrinol 14:911-923. CrossRef

Lu NZ, Shlaes TA, Gundlah C, Dziennis SE, Lyle RE, Bethea CL (1999) Ovarian steroid action on tryptophan hydroxylase protein 
and serotonin compared to localization of ovarian steroid receptors in midbrain of guinea pigs. Endocrine 11:257-267. CrossRef Medline

Luine VN, Rhodes JC (1983) Gonadal hormone regulation of MAO and other enzymes in hypothalamic areas. Neuroendocrinology 36:235-241. Medline

MacLusky NJ, McEwen BS (1978) Oestrogen modulates progestin receptor concentrations in some rat brain regions but not in others. Nature 274:276-278. CrossRef

Mayer LP, Pearsall NA, Christian PJ, Devine PJ, Payne CM, McCuskey MK, Marion SL, Sipes IG, Hoyer PB (2002) Long-term effects of ovarian follicular depletion in rats by 4 -vinylcyclohexene diepoxide. Reprod Toxicol 16:775-781. Medline

Mayer LP, Devine PJ, Dyer CA, Hoyer PB (2004) The follicle-deplete mouse ovary produces androgen. Biol Reprod 71:130-138. CrossRef Medline

Mayer LP, Dyer CA, Eastgard RL, Hoyer PB, Banka CL (2005) Atherosclerotic lesion development in a novel ovary-intact mouse model of perimenopause. Arterioscler Thromb Vasc Biol 25:19101916. CrossRef

McEwen BS (1989) Endocrine effects on the brain and their relationship to behavior. In: Basic neurochemistry: molecular, cellular and medical aspects (Siegel GJ, ed), pp. 893-913. New York: Raven.

Mehra RD, Sharma K, Nyakas C, Vij U (2005) Estrogen receptor alpha and beta immunoreactive neurons in normal adult and aged female rat hippocampus: a qualitative and quantitative study. Brain Res 1056:22-35. CrossRef Medline

Micevych P, Soma KK, Sinchak K (2008) Neuroprogesterone: key to estrogen positive feedback? Brain Res Rev 57:470-480. CrossRef Medline

Michelsen KA, Schmitz C, Steinbusch HWM (2007) The dorsal raphe nucleus-from silver stainings to a role in depression. Brain Res Rev 55:329-342. CrossRef Medline

Mitchell ES, Woods NF (1996) Symptom experiences of midlife women: observations from the Seattle Midlife Women's Health Study. Maturitas 25:1-10. Medline

Mitra SW, Hoskin E, Yudkovitz J, Pear L, Wilkinson HA, Hayashi S, Pfaff DW, Ogawa S, Rohrer SP, Schaeffer JM, McEwen BS, Alves SE (2003) Immunolocalization of estrogen receptor beta in the mouse brain: comparison with estrogen receptor alpha. Endocrinology 144:2055-2067. CrossRef Medline

Monti JM (2010) The structure of the dorsal raphe nucleus and its relevance to the regulation of sleep and wakefulness. Sleep Med Rev 14:307-317. CrossRef Medline

Mora S, Dussaubat N, Díaz-Véliz G (1996) Effects of the estrous cycle and ovarian hormones on behavioral indices of anxiety in female rats. Psychoneuroendocrinology 21:609-620. Medline

Morgan ML, Cook IA, Rapkin AJ, Leuchter AF (2007) Neurophysiologic changes during estrogen augmentation in perimenopausal depression. Maturitas 56:54-60. CrossRef Medline

Munabi AK, Cassorla FG, Pfeiffer DG, Albertson BD, Loriaux DL (1983) The effects of estradiol and progesterone on rat ovarian 17-hydroxylase and 3 beta-hydroxysteroid dehydrogenase activities. Steroids 41:95-98. Medline

Nomura M, Akama KT, Alves SE, Korach KS, Gustafsson J-A, Pfaff DW, Ogawa S (2005) Differential distribution of estrogen receptor (ER)-alpha and ER-beta in the midbrain raphe nuclei and periaqueductal gray in male mouse: predominant role of ER-beta in midbrain serotonergic systems. Neuroscience 130:445-456. CrossRef Medline

O'Connor KA, Ferrell R, Brindle E, Trumble B, Shofer J, Holman DJ, Weinstein M (2009) Progesterone and ovulation across stages of the transition to menopause. Menopause 16:1178-1187.

Ortega-Corona BG, Valencia-Sánchez A, Kubli-Garfias C, Anton-Tay F, Salazar LA, Villarreal JE, Ponce-Monter H (1994) Hypothalamic monoamine oxidase activity in ovariectomized rats after sexual behavior restoration. Arch Med Res 25:337-340. Medline

Osterlund MK (2010) Underlying mechanisms mediating the antidepressant effects of estrogens. Biochim Biophys Acta 1800:11361144. CrossRef
Palkovits M (1973) Isolated removal of hypothalamic or other brain nuclei of the rat. Brain Res 59:449-450. CrossRef

Paxinos G, Watson C (2007) The rat brain in stereotaxic coordinates. Ed 6. San Diego: Academic Press.

Quadros PS, Wagner CK (2008) Regulation of progesterone receptor expression by estradiol is dependent on age, sex and region in the rat brain. Endocrinology 149:3054-3061. CrossRef Medline

Reis FM, Pestana-Oliveira N, Leite CM, Lima FB, Brandão ML, Graeff FG, Del-Ben CM, Anselmo-Franci JA (2014) Hormonal changes and increased anxiety-like behavior in a perimenopause-animal model induced by 4-vinylcyclohexene diepoxide (VCD) in female rats. Psychoneuroendocrinology 49:130-140.

Reyes FI, Winter JS, Faiman C (1977) Pituitary-ovarian relationships preceding the menopause. I. A cross-sectional study of serum follice-stimulating hormone, luteinizing hormone, prolactin, estradiol, and progesterone levels. Am J Obstet Gynecol 129:557-564. Medline

Rissman EF, Heck AL, Leonard JE, Shupnik MA, Gustafsson J-A (2002) Disruption of estrogen receptor beta gene impairs spatial learning in female mice. Proc Natl Acad Sci USA 99:3996-4001. CrossRef Medline

Robichaud M, Debonnel G (2005) Oestrogen and testosterone modulate the firing activity of dorsal raphe nucleus serotonergic neurones in both male and female rats. J Neuroendocrinol 17:179185. CrossRef Medline

Rocha BA, Fleischer R, Schaeffer JM, Rohrer SP, Hickey GJ (2005) 17 Beta-estradiol-induced antidepressant-like effect in the forced swim test is absent in estrogen receptor-beta knockout (BERKO) mice. Psychopharmacology (Berl) 179:637-643. CrossRef Medline

Sá SI, Fonseca BM (2017) Dynamics of progesterone and estrogen receptor alpha in the ventromedial hypothalamus. J Endocrinol 233:197-207. CrossRef Medline

Santoro N, Randolph JF Jr (2011) Reproductive hormones and the menopause transition. Obstet Gynecol Clin North Am 38:455-466. CrossRef

Sasayama D, Sugiyama N, Yonekubo S, Pawlak A, Murasawa $H$, Nakamura M, Hayashi M, Ogawa T, Moro M, Washizuka S, Amano N, Hongo K, Ohnota H (2017) Novel oestrogen receptor $\beta$-selective ligand reduces obesity and depressive-like behaviour in ovariectomized mice. Sci Rep 7:4663. CrossRef Medline

Schmidt PJ, Nieman LK, Danaceau MA, Adams LF, Rubinow DR (1998) Differential behavioral effects of gonadal steroids in women with and in those without premenstrual syndrome. N Engl J Med 338:209-216. CrossRef Medline

Schmidt PJ, Nieman L, Danaceau MA, Tobin MB, Roca CA, Murphy $\mathrm{JH}$, Rubinow DR (2000) Estrogen replacement in perimenopauserelated depression: a preliminary report. Am J Obstet Gynecol 183:414-420. CrossRef Medline

Sharma PK, Thakur MK (2006) Expression of estrogen receptor (ER) alpha and beta in mouse cerebral cortex: effect of age, sex and gonadal steroids. Neurobiol Aging 27:880-887. CrossRef Medline

Shughrue PJ, Lane MV, Merchenthaler I (1997) Comparative distribution of estrogen receptor-alpha and -beta mRNA in the rat central nervous system. J Comp Neur 388:507-525. Medline

Smith LJ, Henderson JA, Abell CW, Bethea CL (2004) Effects of ovarian steroids and raloxifene on proteins that synthesize, transport, and degrade serotonin in the raphe region of macaques. Neuropsychopharmacology 29:2035-2045. CrossRef Medline

Soares CN, Almeida OP, Joffe H, Cohen LS (2001) Efficacy of estradiol for the treatment of depressive disorders in perimenopausal women: a double-blind, randomized, placebo-controlled trial. Arch Gen Psychiatry 58:529-534. Medline

Springer LN, Flaws JA, Sipes IG, Hoyer PB (1996) Follicular mechanisms associated with 4-vinylcyclohexene diepoxide-induced ovotoxicity in rats. Reprod Toxicol 10:137-143. Medline

Stahl SM (2001) Effects of estrogen on the central nervous system. J Clin Psychiatry 62:317-318. Medline

Suzuki H, Barros RPA, Sugiyama N, Krishnan V, Yaden BC, Kim H-J, Warner M, Gustafsson J-Å (2013) Involvement of estrogen recep- 
tor $\beta$ in maintenance of serotonergic neurons of the dorsal raphe. Mol Psychiatry 18:674-680. CrossRef Medline

Takai Y, Canning J, Perez GI, Pru JK, Schlezinger JJ, Sherr DH, Kolesnick RN, Yuan J, Flavell RA, Korsmeyer SJ, Tilly JL (2003) Bax, caspase-2, and caspase-3 are required for ovarian follicle loss caused by 4-vinylcyclohexene diepoxide exposure of female mice in vivo. Endocrinology 144:69-74. CrossRef Medline

Van Kempen TA, Milner TA, Waters EM (2011) Accelerated ovarian failure: a novel, chemically induced animal model of menopause. Brain Res 1379:176-187. CrossRef Medline

Walf AA (2010) Oestrogen receptor beta is involved in the actions of oestrogens in the brain for affective behaviour, but not trophic effects in peripheral tissues. J Neuroendocrinol 22:141-151. CrossRef

Walf AA, Frye CA (2007) Administration of estrogen receptor beta-specific selective estrogen receptor modulators to the hippocampus decrease anxiety and depressive behavior of ovariectomized rats. Pharmacol Biochem Behav 86:407-414. CrossRef Medline

Walf AA, Rhodes ME, Frye CA (2004) Antidepressant effects of ERbeta-selective estrogen receptor modulators in the forced swim test. Pharmacol Biochem Behav 78:523-529. CrossRef Medline

Weiser MJ, Foradori CD, Handa RJ (2008) Estrogen receptor beta in the brain: from form to function. Brain Res Rev 57:309-320. CrossRef Medline

Wiklund I, Karlberg J, Mattsson LA (1993) Quality of life of postmenopausal women on a regimen of transdermal estradiol therapy: a double-blind placebo-controlled study. Am J Obstet Gynecol 168: 824-830. Medline

Yamaguchi-Shima N, Yuri K (2007) Age-related changes in the expression of ER- $\beta$ mRNA in the female rat brain. Brain Res 1155: 34-41. CrossRef Medline 